\title{
OPTIMIZATION OF MANPOWER IN SEAMLESS PIPE THREADING MANUFACTURE BATAM
}

\author{
*Maya Engelin Manopo ${ }^{1}$, Muammar Khaddafi ${ }^{2}$ Indrayani $^{3}$ \\ Department of Management Master Program Batam University, Indonesia \\ Correspondence Address: Jl. Abdulyatama No 5, Batam, Kepulauan Riau. \\ E-mail: ${ }^{1)}$ mayamanopo@gmail.com
}

\begin{abstract}
The objective of manpower optimization is to have the right number of workers with the right capabilities in the right production areas. In this research, a model was developed for optimizing manpower allocation coupling threading area. Total initial manpower allocation is 26 manpower. Improvement executed which consider to customer demand and production capability. Evaluation result indicates there is unbalance workload distribution of each manpower. Improvement planned such as balancing the work load of each manpower, machine replacement, and re-layout the production area. The implementation based on Direct Productivity formula resulted manpower saving cost about 50\%, from 26 manpower to 16 manpower. Standardized work did as well as the control item in order to stabilize the improvement process. The next step is the analysis of production capability to face the increasing of customer demand. This analysis concluded that production needed additional overtime and additional work shift in order to fulfill the customer demand
\end{abstract}

Keywords: manpower optimization, seamless pipe threading, production capability

\section{INTRODUCTION}

Manpower planning is about ensuring that the right types of employees are available at the right place at the right time. The success of the manpower planning is paramount to the survival of the organization and the complexities associated with the planning process and production. Productivity is measured in pcs per man hour, means the amount of goods that can be generated in one hour by several manpower. Productivity thus depends on production output and input in the form of the total number of man power times the hours worked per man power. Total number of manpower allocated in the usual production process measured by man power efficiency. This shows that the man power efficiency value doesn't just have an impact on Manpower wage costs, but also related to productivity.

The threading company has several production areas, one of the area is coupling shop. Coupling shop produce threaded coupling which designated as per API (American Petroleum Institute) standard and other licences. Amount of man power in threading area currently is 26 MP. Improvement studies were carried out to find out whether the current Manpower is still efficient enough compared real working hours and whether the results of improvement is feasible in term of increasing demand.

\section{IMPLEMENTATION METHOD}

Improvement studies were carried out using several concepts and methods. DMAIC is used as steps in doing improvement. The reference method used is The Toyota Production System, which is related to the use of the Takt time as a reference for improvement and elimination of seven types of Muda in the production process. Repair ones done using the concept direct productivity and overall equipment effectiveness. Standardization of work done for process control. (Takahashi, 1992)

International Journal of Social Science, Educational, Economics, Agriculture Research, and Technology (IJSET) 
1. Toyota Production System (TPS)

Toyota Motor Corporation (2006) stated that TPS is an activity at the overall level company, based on the awareness to eliminates waste completely, seeking the rationality of manufacturing means, and develop good manufacturing techniques. Core the goal of the TPS concept itself is the cost reduction or reduction in costs through removal waste thoroughly.

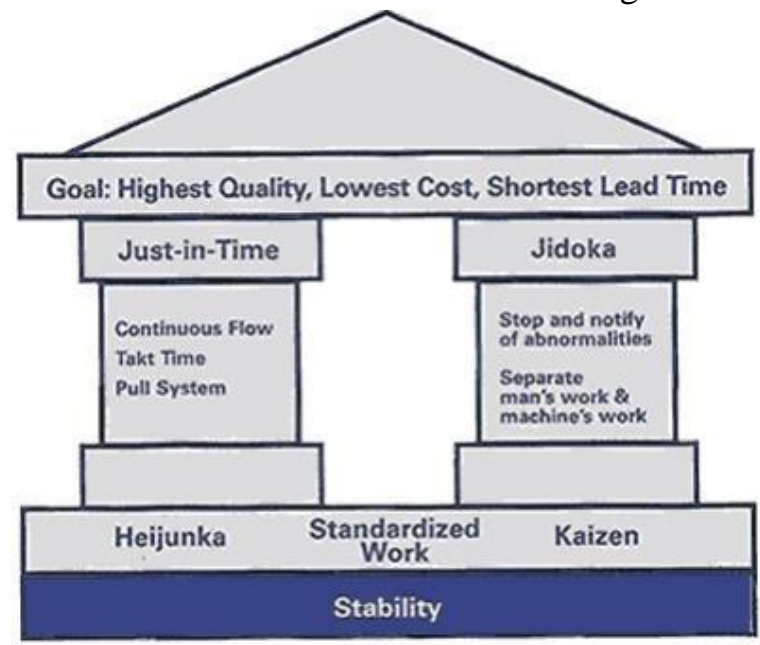

Figure 1. The TPS Framework

Two main pillars in the TPS framework is Just In Time (JIT) and Jidouka or autonomy. The JIT concepts aims to produce and deliver the right parts, in the right amount, at the right time using the minimum necessary resources. This system reduces inventory, and strives to prevents both early and over production. Producing in a JIT exposes problems quickly. With less inventory in a system the "rocks" are quickly exposed in production that are disrupting flow. (Moden,2000)

Jidoka (Build in quality) is the second pillar of the system. There are two parts to Jidoka-1) Building in quality at the process and 2) Enabling separation of man from machine in work environments. The goal is not to run continuously but in other words to stop running automatically when trouble arises. In other words it is better to stop a machine at the first sign of trouble than to keep on producing the problem which only generates more waste. (Elsayes,1994)

\section{OEE}

The OEE (Overall Equipment Effectiveness) is a global indicator for the effectiveness of an equipment. That means that a machine individually or as part of a subsystem must be operating as designed (V.Thebault. 2018). Based on the Opening Time, OEE scrutinizes all type of losses, with the goal of reducing or eliminating them. If it happens however, to have an unscheduled downtime, this downtime must be at very minimum (Yang, 2010). The practical calculation to be used is:

$\mathrm{OEE}=$ Good products $\mathrm{x}$ Standard cycle time

Opening time 
3. Direct productivity

The Direct Productivity is the quantity of direct men.hours needed to produce 1 equivalent product. It can be measured for a line or a workshop. (V.Thebault. 2018)

The Direct Productivity is given by:

Direct productivity $=$ Total paid hours of direct manpower

Total Equivalent Production

The paid hour of manpower includes all paid hours without exception (and including training). Temporary workers shall also be included in the perimeter because they also add value to the product. The Total Equivalent Production is determined using the Cycle Time table. Hours and equivalent products shall be calculated for the same period. (D.H. Stamatis, 2011)

\section{Seven types of Muda}

A job can be divided into three namely valuable work or giving core work added value, non-valuable work but necessary to do, work that does not provide value added but still required such a process put the part on the machine. The third type of work namely non valuable work and not needed this work is referred to as Muda or extravagance in TPS. Muda is always endeavored to be eliminated in the TPS. (PT Astra Otoparts. 2008)

\section{Standardization of Work}

Standardization of work is necessary made as a reference in the production process. To be nominal, variabilities must be identified and eliminated. Standard work make the work defined precisely and clearly in order to understand, share, and apply what is nominal. Standardization work is an effective way as tools in kaizen or continuous improvement. (PT Astra Otoparts, 2008)

\section{RESULTS AND DISCUSSION}

Analysis of the discussion will be carried out sequential from initial conditions analysis, Muda potential analysis, improvement plans, and evaluation of improvements to analize whether the results of improvement is feasible in term of increasing demand.

\section{Initial Situation}

Currently coupling threading line have a total 26 manpower. For one threading machine is placed 2 personnel. One threading machine operator is for handling activities; and the other is production controller or gauging inspector for inspection activities. Production process starts with the operator begin the tooling preparation, material preparation and until machining process. After first output finished, gauging inspector begin the inspection activities.

Table 1. Handling Activities

\begin{tabular}{|c|c|c|}
\hline No. & Handling Activities & Time (s) \\
\hline 1 & Loading material into CNC & 20 \\
\hline 2 & Loading material into waiting material rack & 25 \\
\hline 3 & Loading material into waiting material rack & 25 \\
\hline
\end{tabular}


Volume 1 Issue 2 (2022)

OPTIMIZATION OF MANPOWER IN SEAMLESS PIPE THREADING MANUFACTURE BATAM DOI: https://doi.org/10.54443/ijset.v1i2.7

\begin{tabular}{|c|c|c|}
\hline 4 & Checking ID & 30 \\
\hline 5 & Chcecking ID and Swap Side & 85 \\
\hline 6 & Loading material into waiting material rack & 20 \\
\hline 7 & Checking ID & 35 \\
\hline 8 & Checking ID clean chip from thread, loading out & 60 \\
\hline \multicolumn{2}{|c|}{ Total Handling Activities Duration/ 1pcs coupling } & 300 \\
\hline
\end{tabular}

Table 2. Inspection Activities

\begin{tabular}{|c|l|l|}
\hline No. & Inspection Activities & Time (s) \\
\hline 1 & Cleaning using vacuum cleaner & 47 \\
\hline 2 & Manual Deburring & 45 \\
\hline 3 & Coupling no. record to report & 5 \\
\hline 4 & Gauging Inspection activity & 365 \\
\hline 5 & Final cleaning and touch up & 120 \\
\hline 6 & Loading into basket & 30 \\
\hline Total Inspection Activities Duration/ 1pcs coupling & \\
\hline
\end{tabular}

Table 3. Activities Comparation

\begin{tabular}{|c|c|}
\hline Type of Activity & Time (minute) \\
\hline Machining Time & 15 \\
\hline Handling Time & 5 \\
\hline Inspection Time & 10.2 \\
\hline
\end{tabular}

The total working time to produce one output is the total working time of the machining which include handling activities, and the inspection activities. Based on table. 3 shows that there is no workload balance shown through unbalanced manpower uptime between handling and gauging. Total time needed for one output becomes 15 minutes during machining and another 10 minutes to inspection. The steps got to do is to balance workload by eliminating some work elements or can be replaced by other operations as well with combine several elements of work into one work station.

\section{Muda Potencial}

Direct observations into the workshop indicate there are several Muda potencials or waste such as waste of processes, waste of time, waste of movement, and waste of transportation. Those waste need to be minimized or eliminated. Muda potencies is analized using 5-Why Analysis as a basis of reference to plan on some production area imporvements. 


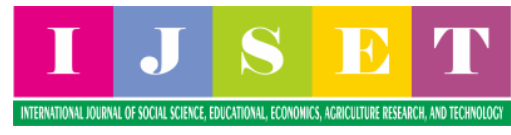

Table 4. Muda potencials

\begin{tabular}{|c|c|}
\hline Root Cause & Action \\
\hline $\begin{array}{c}\text { Some operators didn't train as gauging } \\
\text { inspector yet }\end{array}$ & $\begin{array}{c}\text { Operators will follow MUSO (Multi Skill } \\
\text { Operator) Program to complete their gauging } \\
\text { inspection qualification. }\end{array}$ \\
\hline $\begin{array}{c}\text { Current gauging inspection table } \\
\text { position not facing CNC machine }\end{array}$ & $\begin{array}{r}\text { New gauging inspection tables and } \\
\text { workstation layout are needed and will be } \\
\text { arranged properly. }\end{array}$ \\
\hline $\begin{array}{c}\text { Operator should walk to input area then } \\
\text { output area after inspection by himself }\end{array}$ & $\begin{array}{c}\text { Chain hoist will be relocated according to } \\
\text { new workstation layout design }\end{array}$ \\
\hline
\end{tabular}

The result of Muda potency shows that a few improvements can be done, such as machine replacement, additional equipment for handling and transportation, layout modification, also personnel training and qualification.

\section{Improvement Plan}

Improvement plan for several problems that have been analyzed in the analysis of Muda potential is created and analyzed its possibilities of implementation and related impact.

1. Re-layout Threading Area

The first improvement is the re-layout of the work area using the C-round layout concept. The aim is to narrow the distance between machines to inspection area so as to reduce the movement time of the manpower operating machines and doing the inspection. This improvement needs to be done to facilitate the $\mathrm{C}$ Formation to be achieved due to the reduced material transportation time from one work area to another.
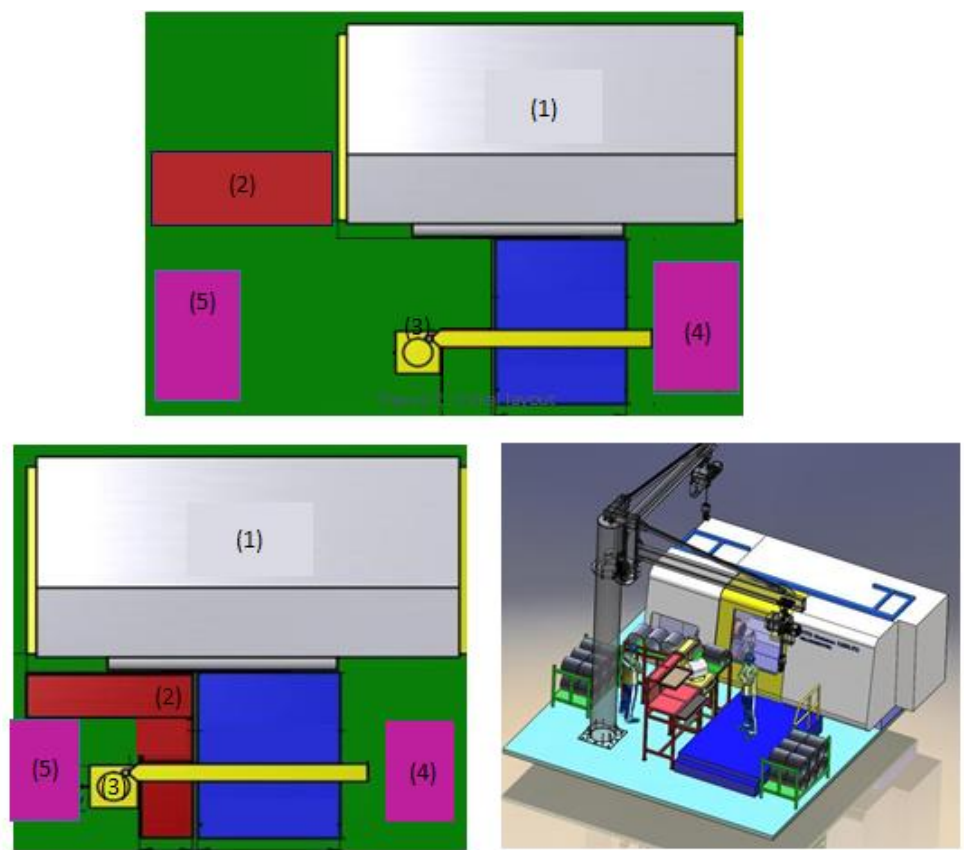

Figure 3. Layout after improvement 
Note:

(1) Machine area

(2) Inspection area

(3) Crane

(4) Incoming material

(5) Output material

2. Modification of handling tools and machine replacement

The second improvement is to modify the handling tools and to replace the threading machine with the latest improved technology. Modification of handling tools is to combine the material moving access and their placement position, so that when the threading machine operating, the personnel can do the handling and inspection material.

Modification of handling tools is to reduce Muda process which happened before such as operator should walk to input area and then to ouput area after inspection by himself. Those element can be reduced by move the jig crane position for more area cover, to install proper gauge placement, to install roller for threading inspection, to install conveyor for coupling transportation, and to make optimum height for work floor to improve the ergonomic factor of personnel.

\section{Workload balancing}

The result of layout and handling tool improvements make manpower optimization possible to do. Direct productivity formula can be used to check if the production will be more effective with 1 personnel. With the old version machine, total work hour of one machine is 15 minutes and work hours of inspection is 10.2 minutes. Number of machines in couping workshop area is 13 machines, each machine placed 2 personnel. These results can be concluded that the $\mathrm{C}$ Formation is better to implement.

\section{Improvement Evaluation}

Improvement evaluation is done by recalculating average output unit per hour, activities time, and cost saving in manpower optimization. These results will be compared with the initial conditions.

Table below is the after improvement condition which using new machine and other handling improvement with only one personnel in charge.

Table 5. Handling activities after improvement

\begin{tabular}{|c|l|c|}
\hline No. & \multicolumn{1}{|c|}{ Handling Activities } & Time (s) \\
\hline 1 & Loading material into CNC & 20 \\
\hline 2 & Loading material into waiting material rack & 25 \\
\hline 3 & Loading material into waiting material rack & 25 \\
\hline 4 & Chcecking ID and Swap Side & 85 \\
\hline 5 & Loading material into waiting material rack & 20 \\
\hline 6 & Checking ID clean chip from thread, loading out & 60 \\
\cline { 1 - 2 }
\end{tabular}




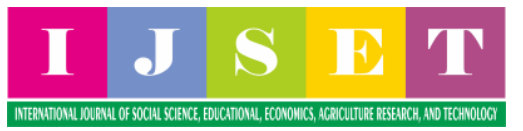

Total Handling Activities Duration/ 1pcs coupling

Table 6. Inspection activities after improvement

\begin{tabular}{|c|l|c|}
\hline No. & \multicolumn{1}{|c|}{ Inspection Activities } & Time (s) \\
\hline 1 & Cleaning using vacuum cleaner & 47 \\
\hline 2 & Manual Deburring & 45 \\
\hline 3 & Coupling no. record to report & 5 \\
\hline 4 & Gauging Inspection activity & 365 \\
\hline 5 & Final cleaning and touch up & 120 \\
\hline 6 & Loading into basket & 30 \\
\hline Total Inspection Activities Duration/ 1pcs coupling & 612 \\
\hline
\end{tabular}

Table 7. Activities comparation after improvement

\begin{tabular}{|l|c|}
\multicolumn{1}{|c|}{ Type of Activity } & Time (minute) \\
\hline Machining Time & 15 \\
\hline Handling Time & 3.9 \\
\hline Inspection Time & 10.2 \\
\hline
\end{tabular}

The result of time needed shows in table. 7 that the total time needed to produce one output is the same with the previous condition which has 2 personnel involved.

Table 8. Comparison of final result and initial situation

\begin{tabular}{|c|c|c|c|} 
& Initial & Improved & Unit \\
\hline $\begin{array}{c}\text { Time consume } \\
\text { Machine capacity }\end{array}$ & 2.77 & 3.86 & pcs/hour \\
Total manpower & 28 & 16 & person \\
$\begin{array}{c}\text { Direct } \\
\text { productivity }\end{array}$ & 1.32 & 0.66 & point \\
\hline
\end{tabular}

Achievement of improved results shows an increase in machine capacity by $71 \%$. By operating and doing inspection at once it will be decreasing a half of manpower cost which shown in the decrease of direct productivity point by $50 \%$. The results of these improvements do not stop with the implementation process, but are also standardized using several standardized 
TPS work tools. The standardization process is needed so that the improvement results do not decrease back to the initial conditions.

\section{Production Capability Facing Increasing Demand}

The results of the improvements show that the production capacity to meet the demand needs until October 2020 is enough by using only 1 manpower per machine. However, the amount of consumer demand for products for years ahead has the possibility to increase from the previous months, causing the overal equipment efficiency needs to be reviewed.

The strategy analysis that companies should take related to this issue will be discussed further, namely the selection of strategic options that can be taken between over time (OT) or additional work shifts. The analysis will be determined based on the amount of total salary costs to be paid for each given plan. The summary of the calculation results shows the plan to allocate overtime working hours and shift arrangements with the smallest total salary.

\section{CONCLUSION}

Improvements to the coupling threading area have been carried out by resulting in savings in the amount of manpower by 13 manpower. The results of these improvements also resulted an increase in machine capacity by $71 \%$, an increase in manpower efficiency by $50 \%$ and a decrease in direct production by $50 \%$. The results of the analysis of production capability in the face of rising demand also showed that production was still capable of up to end of 2020. An increase in demand in next years can be anticipated with additional OT and additional work shifts based on the analysis results.

\section{REFERENCES}

Adi Wijaya, S. ., Hanum, S. ., \& Khaddafi, M. . (2021). THE EFFECT OF MARKETING CHANNELS AND PACKAGING ON BUSINESS SUCCESS IN STANDARD BUSINESSES IN THE CITY OF LHOKSUMAWE: (Case Study on Internet Data Package Merchants). International Journal of Social Science, Educational, Economics, Agriculture Research, and Technology (IJSET), 1(1), 21-28. https://doi.org/10.54443/ijset.v1i1.3

Elsayed, E.A., Boucher T. O. (1994). Analysis and Control of Production System: Second edition. New Jersey: Prentice-Hall International, Inc.

D.H. Stamatis. (2011). The OEE Primer: Understanding Overall Equipment Effectiveness, Reliability, and Maintainability. New York: CRC Press - Taylor and Francis Group.

Liker, J. K., Meier, D. (2006). The Toyota Way Fieldbook: a Practical Guide for implementing Toyota's 4Ps. New York: McGraw-Hill.

Monden, Y. (2000). Sistem Produksi Toyota: Suatu Ancangan Terpadu Untuk Penerapan JustIn-Time 2. Jakarta: PPM \& Yayasan Toyota \& Astra.

PT Astra Otoparts. (2008). Toyota Production System: Training \& Education Center. Jakarta: Author.

Riinawati, R. (2021). The Development of Information Technology and Its Influence on the Field of Management Accounting. Journal of Financial and Tax, 1(2), 131-149.

Sinurat, M., Ilham, R. N., \& Cen, C. C. (2021, February). Asetpedia. id as a Start-Up Based Technology Benchmarking Innovation for Beginning Companies in the North Sumatera Region. In International Conference on Strategic Issues of Economics, Business and, Education (ICoSIEBE 2020) (pp. 109-114). Atlantis Press. 